\title{
Gravity-driven 1-D consolidation of cemented paste backfill in 3-m-high columns
}

\author{
Tikou Belem $^{1}$ (D) Omar El Aatar ${ }^{1} \cdot$ Bruno Bussière $^{1} \cdot$ Mostafa Benzaazoua $^{1}$
}

Received: 25 June 2016/ Accepted: 26 August 2016/Published online: 6 September 2016

(C) Springer International Publishing Switzerland 2016

\begin{abstract}
This paper investigates and simulates the effect of underground placement conditions of cemented paste backfill (CPB) on the evolution of its physical and mechanical properties. Experimental setups that consist of $\mathrm{PVC}+$ Makrolon ${ }^{\circledR}$ GP polycarbonate sheet columns, each $3 \mathrm{~m}$ high, were built and filled with CPB at two different backfill plants. These setups allow simulating undraine$\mathrm{d}$ (UD), partial lateral drainage (PLD) and full lateral drainage (FLD) conditions and the measurement of resulting self-weight consolidation settlement of CPB. The results show that maximum drainage water percentages of 15 and $8 \%$ of the CPB total initial water were observed for the FLD and the PLD columns. The results also suggest that in situ backfilled stopes behave in a similar way to that of FLD or PLD conditions.
\end{abstract}

Keywords Cemented paste backfill $\cdot$ Drainage $\cdot$ Selfweight consolidation $\cdot$ Filling rate $\cdot$ Column tests

\section{Introduction}

Cemented paste backfilling technique, which uses a viscous mixture made of mine tailings filter cake, a binding agent and mixing water to reach a target slump between 152 and $254 \mathrm{~mm}$ (i.e, 6-10 in.), is becoming a common practice in underground hard rock mines worldwide since the 90's (e.g., [1]). Figure 1 is a schematic illustration of the

Tikou Belem

tikou.belem@uqat.ca

1 Research Institute of Mining and Environment, Universite du Quebec en Abitibi Temiscamingue, 445, boul. de l’Universite, Rouyn-Noranda J9X 5E4, QC, Canada cemented paste backfill (CPB) mixture preparation process. However, the nature of cemented paste backfill material is very complex due to the wide variability of tailings and binder types used. Indeed, the hydromechanical and geochemical properties of CPB material are in continuous change since their preparation to their placement underground and hardening [2, 3].

Moreover, the in situ mechanical and curing properties of $\mathrm{CPB}$ vary greatly, depending on the mixing process during its preparation, placement and the conditions of the mine environment [4-9]. Figure 2 schematically illustrates the overview of the factors that may affect the properties of $\mathrm{CPB}$ deposited in underground open stopes. To obtain more realistic physical and mechanical responses of $\mathrm{CPB}$, it is inevitable to take into account all these factors that include the: (i) heat load and curing conditions, (ii) stope geometry, (iii) self-weight consolidation or time-dependent surcharge loadings, (iv) physical, chemical and mineralogical properties of ingredients (tailings, water, binder), (v) placement and interaction between backfill and stope walls, (vi) geostatic stress field, (vii) dynamic loading, (viii) barricade load, (ix) arching effect, (x) stope walls convergence and (xi) rheology and transport of $\mathrm{CPB}$ preparation.

Some recent studies have showed that for identical CPB mix recipe and curing time, the unconfined compressive strength (UCS) of in situ CPB core samples could be 2-6 times higher than the UCS of specimens from the same CPB mix recipe poured into plastic molds for quality control purpose [4-6, 10-14]. Also, the same observations were made for CPB samples prepared and cured in laboratory conditions compared to in situ underground $\mathrm{CPB}$ samples as shown in Fig. 3 [15-17]. The discrepancies in compressive strength could be explained partly by the fact that the hardening process of $\mathrm{CPB}$ cured under field 


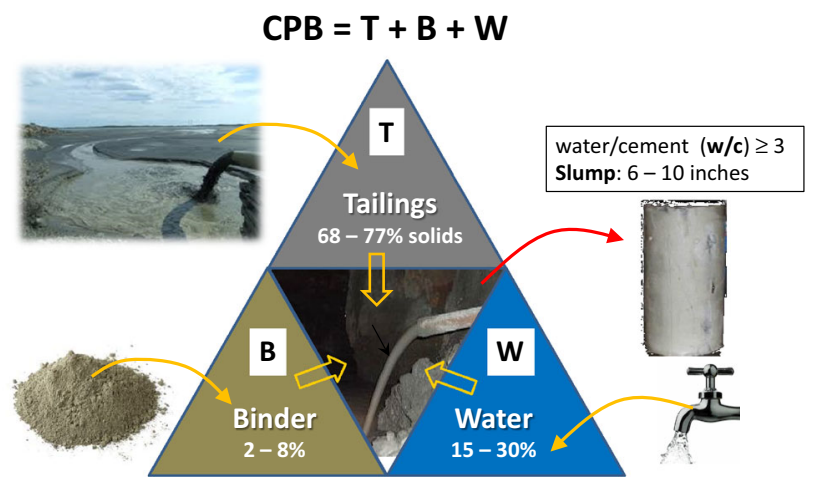

Fig. 1 Schematic illustration of the cemented paste backfill (CPB) mixture preparation process

effective stresses enhanced the rate of shear and compressive strengths development as reported by numerous authors $[4,7,16-27]$.

Other factors of influence are the water bleeding and the gravity-driven consolidation settlement (self-weight consolidation) of the CPB mass which may depend on its physical-geochemical properties and also on the physical properties of the surrounding rock mass (fracturing). It was reported that this self-weight consolidation settlement can reach more than $1 \mathrm{~m} \mathrm{[11]} \mathrm{and} \mathrm{is} \mathrm{usually} \mathrm{considered} \mathrm{to} \mathrm{be}$ beneficial for the CPB strength development $[4,10]$. Indeed, due to gradual reduction in the void ratio after consolidation, the CPB stiffness tends to increase over the curing time $[5,10,11,14,17,21,28,29]$. There is no conventional procedure of underground stope filling sequencing, and some mines choose continuous filling without a plug-fill, while others choose the batch filling with a plug-fill [29]. In some cases, a continuous filling

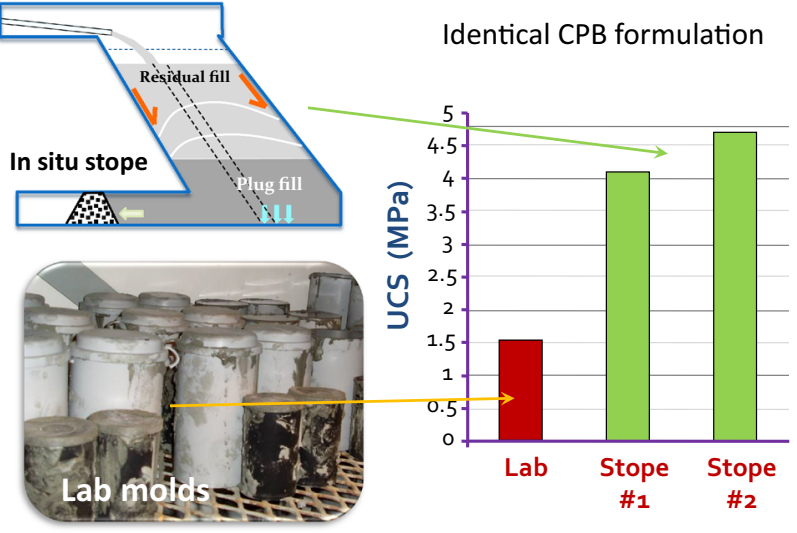

Fig. 3 Comparison between Louvicourt (LVT) mine stope CPB core specimens and lab mold specimens UCS values

may yield barricade failures due to the buildup of excess pore water pressure during placement [30]. Thus, it is of great importance to understand self-weight and surcharge load consolidation characteristics of fresh CPB materials.

A relatively large number of experimental studies are reported in the literature on the self-weight consolidation of granular slurries, debris, dredge materials or waste rock and mine tailings $[31,32]$. The originality of the present study, however, is that it considers high-density slurry (solids mass concentration ranging between 70 and $85 \% \mathrm{w} / \mathrm{w})$. Only limited numbers of investigation on the consolidation behavior of $\mathrm{CPB}$ have been completed to date [4, 33-36].

The purpose of this paper is to investigate the physical and mechanical properties of CPB prepared at two paste backfill plants belonging to two Canadian mines (LVT and

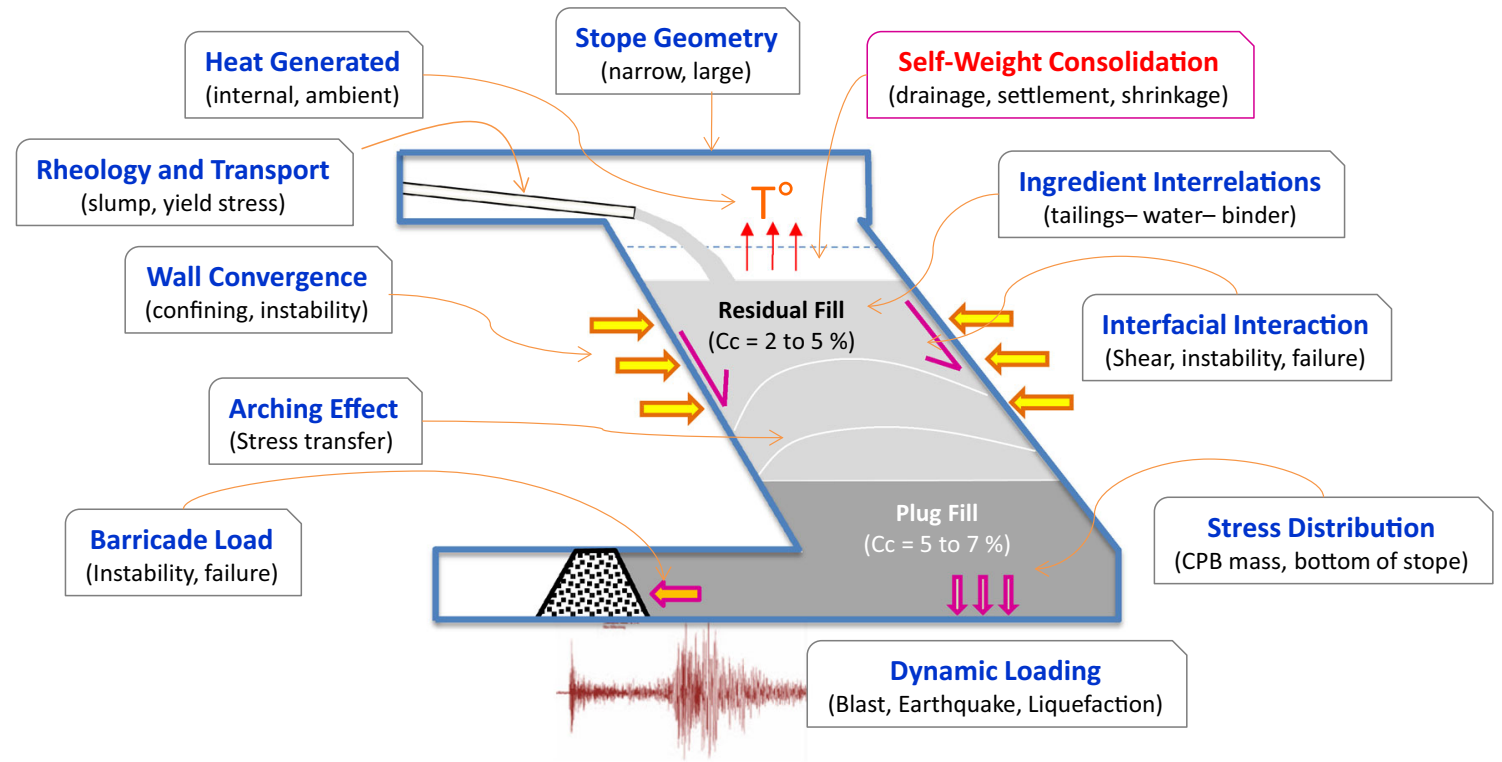

Fig. 2 Schematic illustration of the main factors affecting the in-stope CPB properties 
LRD), poured and cured into 3-m-high PVC+Makrolon ${ }^{\circledR}$ transparent polycarbonate sheets columns following. Different drainage scenarios were considered, including undrained, lateral and vertical drainage conditions. The main objective is to better understand the effect of selfweight consolidation settlement of CPB on its physical and mechanical properties.

\section{Materials and methods}

\section{CPB self-weight consolidation in columns}

In-stope CPB self-weight consolidation can occur through different drainage scenarios either laterally (across the stope walls) or at the base of the stope (usually impervious). In this study, the gravity-driven consolidation tests were performed at the LRD (tailings sample CT1) and LVT (tailings sample CT2) mine backfill plants in Quebec, Canada. To simulate CPB placement in underground mine stope and its self-weight consolidation, three PVC+Makrolon ${ }^{\circledR}$ GP transparent polycarbonate sheet columns having $31.5 \times 30.5 \mathrm{~cm}^{2}$ section and $300 \mathrm{~cm}$ height were manufactured. The columns allow simulating an actual stope backfilling sequence as well as various configuration of the CPB drainage scenarios (lateral and vertical). Indeed, the columns may be configured such that different water drainage scenarios of the $\mathrm{CPB}$ can be simulated.

\section{Drainage scenarios}

The CPB water drainage is allowed through a seal of geotextile while it is prevented using a rubber seal (undrained case).

For LRD mine backfill CT1, a single drainage scenario was investigated and which is lateral + vertical drainage occurring simultaneously: that is to say, full lateral drainage (FLD) combined with vertical drainage (VD). In this case, the drainage is allowed along the entire height of the column and at the base of the columns $(\mathrm{FLD}+\mathrm{VD})$. Also, pore water pressure in the backfill CT1 columns was measured using pressure sensors installed at 70 and $180 \mathrm{~cm}$ from the base of the columns (Figs. 4a, 5a).

For LVT mine backfill CT2, three drainage scenarios were investigated: a full lateral drainage (FLD) column where drainage is allowed along the entire height of the column (base case), a partial lateral drainage (PLD) column where drainage is allowed only on the lower half of the column (intermediate case) and undrained (UD) column where drainage is not allowed as the drain valve is kept closed but bleeding can occur (control) (Figs. 4b, 5b).

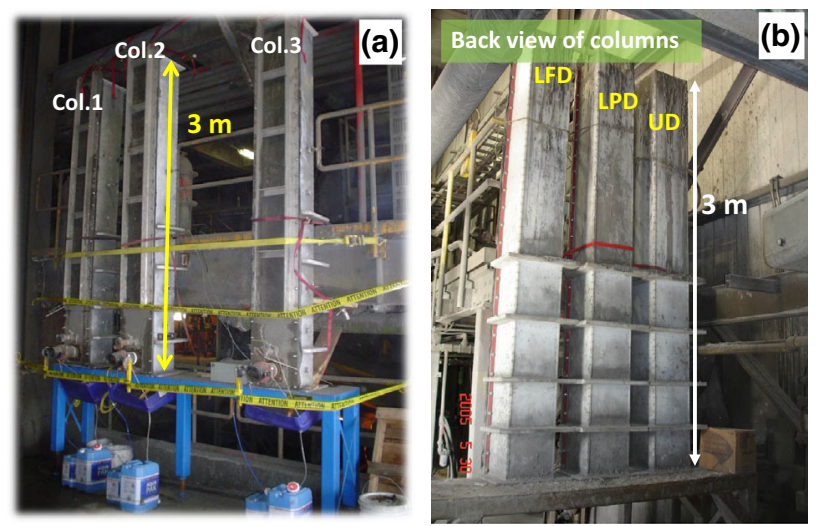

Fig. 4 Photos of the consolidation columns used at: a LRD mine backfill plant, b LVT mine backfill plant

For both backfills CT1 and CT2, the drainage water (vertical and laterally) was collected in different plastic containers to be weighted in a constant time interval (see Figs. 4, 5).

\section{Backfill materials}

Figure 6 presents the grain size distribution (GSD) curves of the two tailing samples CT1 (LRD mine) and CT2 (LVT mine) used for the cemented paste backfill preparation.

The GSD curves were determined on homogenized tailing samples using a Malvern Mastersizer S $2000^{\circledR}$ laser particle analyzer. The GSD analysis showed that about $58 \%$ of the tailings sample CT1 and $48 \%$ of the tailings sample CT2 are finer than $20 \mu \mathrm{m}$ (i.e., ultrafine particles content or $\left.\mathrm{P}_{20 \mu \mathrm{m}}\right)$; the clay-sized particles $(d<2 \mu \mathrm{m})$ content is in the range $7-8 \%$, the silt-sized particles $(2<d \leq 75 \mu \mathrm{m})$ content is in the range $78-84 \%$, and the sand-sized particles $(75<d \leq 5000 \mu \mathrm{m})$ content is in the range $17-22 \%$. Most of the GSD falls into medium to fine sand and silt-sized grains. According to the Unified Soil Classification System (USCS), the tailing samples CT1 and CT2 can be classified as low plastic silts (ML). Table 1 summarizes the physical characteristics of the two mine tailing samples used.

The CPB used at LRD mine was prepared using the full stream tailings, lake water and three different binder formulations (see Fig. 5a). That is to say that three different backfill mix recipes were prepared, and each column was filled with a single mix recipe: column 1 with $100 \%$ of general use Portland cement GU (CT1-Col.1), column 2 with a blended binder of $50 \%$ GU/50 \% Slag (CT1-Col.2) and column 3 with a blended binder of $50 \%$ GU/50 \% HS (HS is the high sulfate-resisting Portland cement) (CT1-Col.3).

The CPB used at LVT mine (tailings sample CT2) was made up of slightly deslimed tailings (by $5 \%$ of minus 20 $\mu \mathrm{m}$ particle size), which means that $\mathrm{P}_{20 \mu \mathrm{m}}$ was reduced 

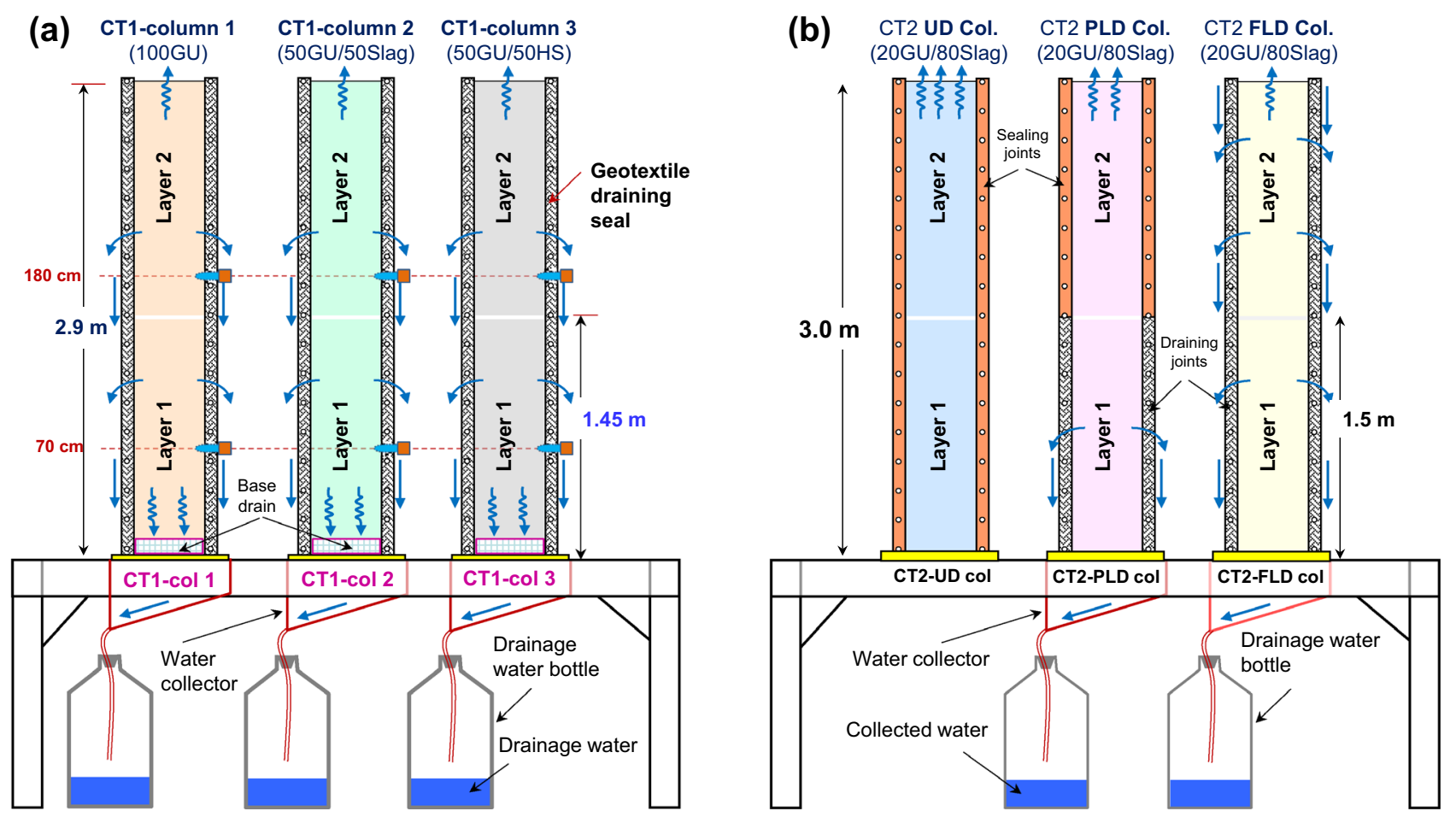

Fig. 5 Schematic diagrams of the three consolidation columns (modified from [18] and [37]) used at: a LRD mine backfill plant, b LVT mine backfill plant

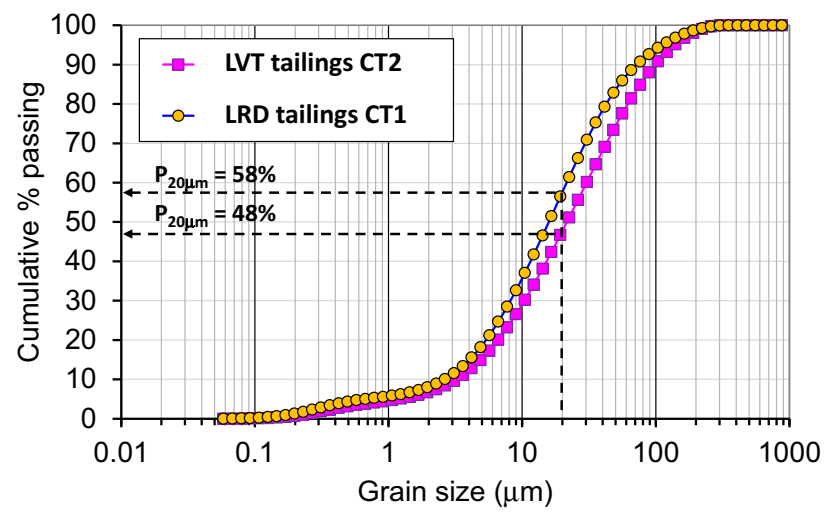

Fig. 6 Grain size distribution curves of the two mine tailing samples used

from 53 to $48 \%$ to improve the compressive strength of the CPB. The deslimed tailings were then mixed with the recycled mine process water with a slag cement which is a blend of $20 \%$ general use Portland cement and $80 \%$ ground-granulated blast-furnace slag; $20 \%$ GU/80 \% Slag (Fig. 5b).

At the end of the mixing process, the LVT mine backfill CT2 has a final standard cone slump height of $19.8 \mathrm{~cm}$ (7.8 in.), while this value was set to $26.7 \mathrm{~cm}$ (10.5 in.) at the LRD mine backfill CT1. Table 2 presents the main characteristics of the LRD mine (CT1) and LVT mine (CT2) cemented paste backfill formulations.
The LRD mine paste backfill mixtures (CT1) used for columns 1, 2 and 3 filling were prepared at the LRD mine backfill plant. The final mixtures contained $5 \%$ of binder and solid mass concentration $C_{\mathrm{w}}$ of $76 \%$. The resulting initial void ratio is 1.22 ; the bulk unit weight is $22.1 \mathrm{kN} /$ $\mathrm{m}^{3}$, while the dry unit weight is $16.8 \mathrm{kN} / \mathrm{m}^{3}$ (see Table 3).

The LVT mine paste backfill mixtures (CT2) used for filling the UD, FLD and PLD columns were prepared at the LVT mine backfill plant. A single backfill mix recipe was used with a blended binder $20 \%$ GU/80 \% slag. The final mixture contained $4.5 \%$ of binder and solid mass concentration $C_{\mathrm{w}}$ of $75.8 \%$. The resulting initial void ratio is 1.12 ; the bulk unit weight is $21.4 \mathrm{kN} / \mathrm{m}^{3}$, while the dry unit weight is $16.2 \mathrm{kN} / \mathrm{m}^{3}$ (see Table 3).

\section{Methods}

\section{Sequence of filling the columns}

The sequence of filling a mine stope plays an important role in the resulting backfill self-weight consolidation. In most cases, the sequence of filling an open stope is to first pour a plug-fill of few meters high, followed by pouring the residual fill. The plug-fill is usually left to cure between 24 and $120 \mathrm{~h}$ prior to the residual filling to avoid excess pressure on the barricade $[6,29]$. Also, there is no standard 
Table 1 Physical characteristics of tailings CT1 and CT2
Table 2 The LRD mine (CT1) and LVT mine (CT2) backfill formulations and characteristics

\begin{tabular}{lll}
\hline Parameter (units) & Values & \\
\cline { 2 - 3 } & Tailings sample CT1 & Tailings sample CT2 \\
\hline Specific gravity, $G_{\mathrm{s}}$ & 3.7 & 3.5 \\
Ultrafine content $\mathrm{P}_{20 \mu \mathrm{m}}(\%)$ & 58 & 48 \\
Fines content $\mathrm{P}_{75 \mu \mathrm{m}}(\%)$ & 91.5 & 85 \\
Clay size particles content $\mathrm{P}_{<2 \mu \mathrm{m}}(\%)$ & 8 & 6.7 \\
Silt size particles content $\mathrm{P}_{2-75 \mu \mathrm{m}}(\%)$ & 83.5 & 78.3 \\
Sand size particles content $\mathrm{P}_{75-5000 \mu \mathrm{m}}(\%)$ & 16.5 & 21.7 \\
$D_{10}$, effective particle size $(\mu \mathrm{m})$ & 2.7 & 3.1 \\
$D_{30}$, size of $30 \%$ passing $(\mu \mathrm{m})$ & 8 & 10.5 \\
$D_{50}$, average particle size $(\mu \mathrm{m})$ & 16.6 & 22.5 \\
$D_{60}$, size of $60 \%$ passing $(\mu \mathrm{m})$ & 22.5 & 30.5 \\
$D_{90}$, size of $90 \%$ passing $(\mu \mathrm{m})$ & 80 & 90 \\
USCS classification & ML (low plastic silt) & ML (low plastic silt)
\end{tabular}

Table 3 Various geotechnical parameters of the backfills CT1 and CT2

\begin{tabular}{lll}
\hline Parameter & LVT mine tailings (CT2) & LRD mine tailings (CT1) \\
\hline Binder type & $20 \%$ GU/80 \% Slag & $100 \%$ GU (col. 1) \\
& & $50 \%$ GU/50 \% Slag (col. 2) \\
Binder content $B_{\mathrm{w}}$ & $4.5 \%$ (by dry mass of tailings) & $50 \%$ GU/50 \% HS (col. 3) \\
Drainage configuration & UD (undrained) & FLD + VD (column 1) \\
& PLD (partial lateral drainage) & FLD + VD (column 2) \\
Mixing water & FLD (full lateral drainage) & FLD + VD (column 3) \\
Standard slump height & Recycled mine water & Lake water \\
\hline
\end{tabular}

\begin{tabular}{llllllll}
\hline Parameters & \multicolumn{5}{l}{ Backfill CT1 } & & \multicolumn{3}{l}{ Backfill CT2 } \\
\cline { 2 - 3 } & Col. 1 & Col. 2 & Col. 3 & & UD col. & PLD col. & FLD col. \\
\hline Solid content, $C_{\mathrm{w}}(\%)$ & 76 & 76 & 76 & & 75.8 & 75.8 & 75.8 \\
Total volume, $V_{\mathrm{T}}(\mathrm{L})$ & 279 & 279 & 279 & & 288 & 288 & 288 \\
Bulk density, $\rho_{\mathrm{h}}\left(\mathrm{kg} / \mathrm{m}^{3}\right)$ & 2150 & 2146 & 2151 & & 2180 & 2180 & 2180 \\
Specific density, $\rho_{\mathrm{s}}\left(\mathrm{kg} / \mathrm{m}^{3}\right)$ & 3624 & 3609 & 3625 & & 3500 & 3500 & 3500 \\
Total mass, $M_{\mathrm{T}}(\mathrm{kg})$ & 599.03 & 597.91 & 599.31 & & 628.33 & 628.33 & 628.33 \\
Mass of water, $M_{\mathrm{w}}(\mathrm{kg})$ & 143.8 & 143.5 & 143.8 & & 152.06 & 152.06 & 152.06 \\
Mass of solid, $M_{\mathrm{s}}(\mathrm{kg})$ & 455.3 & 454.4 & 455.5 & & 476.3 & 476.3 & 476.3 \\
Volume of solid, $V_{\mathrm{s}}(\mathrm{L})$ & 125.62 & 125.91 & 125.65 & & 136.08 & 136.08 & 136.08 \\
Volume of void, $V_{\mathrm{v} 0}(\mathrm{~L})$ & 153.4 & 153.1 & 153.4 & & 151.9 & 151.9 & 151.9 \\
Initial void ratio, $e_{0}$ & 1.22 & 1.22 & 1.22 & & 1.12 & 1.12 & 1.12 \\
\hline
\end{tabular}

procedure of stope sequence of filling, because some mines opt for continuous filling without a plug-fill, while others choose the batch filling with a plug-fill.

Since the CPB was prepared directly into the mixer of the backfill plant at the two mine sites, and since the vertical scale factor between the columns and the actual stopes is 10 , it was decided not to simulate the actual sequence of filling. Instead, the three columns were filled with the backfill (CT1 and CT2) in two sequences (stages) of filling as illustrated in Fig. 5. For the tests performed at the two mine backfill plants (LRD and LVT), it was chosen to fill the columns in two sequences (layers) with a rest time of $12 \mathrm{~h}$ (a total period of $24 \mathrm{~h}$ ). Thus, the first layers (or sequences) in the three columns were all filled within the first $12 \mathrm{~h}$ of the first day, while the second layers were filled within the next $12 \mathrm{~h}$ following the second day for a 

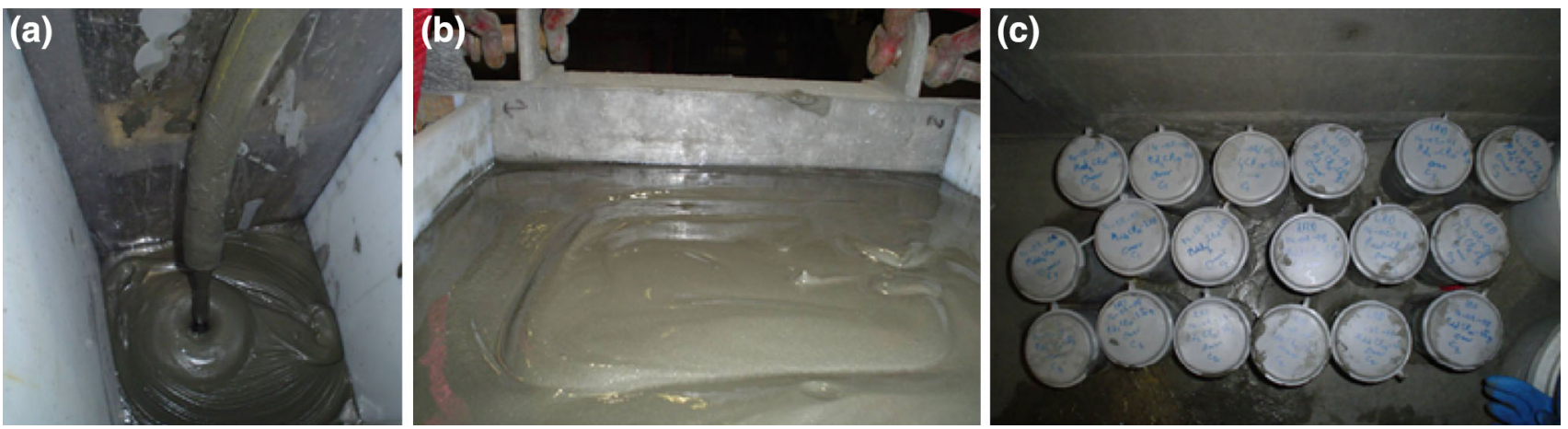

Fig. 7 Photographs showing the columns filling and plastic molds filled with CT1 and CT2 paste backfill

total time period of $24 \mathrm{~h}$ to complete the filling of columns (Fig. 7a, b). The backfill self-weight consolidation settlement was manually measured for each column at a time interval of about $1 \mathrm{~h}$. The total duration of the measurements was 5 days.

For the tests at LRD mine, the three columns were filled in two layers each of $1.45 \mathrm{~m}$ thickness, within the first $12 \mathrm{~h}$ of the first day (equivalent filling rate of $0.121 \mathrm{~m} / \mathrm{h}$ ). Then, the filled columns were left to cure/consolidate in ambient air at the LRD paste backfill plant for a curing period of 94-day for the CT1-column 1 backfill (binder $=100 \% \mathrm{GU}), 98$-day for the CT1-column 2 backfill (binder $=50 \%$ GU/50 \% Slag), and 102-day for the CT1column 3 backfill (binder $=50 \%$ GU/50 \% HS).

For the tests at LVT mine, the three columns were filled also in two layers each of $1.5 \mathrm{~m}$ thickness, within the first $12 \mathrm{~h}$ of the first day (equivalent filling rate of $0.125 \mathrm{~m} / \mathrm{h}$ ). Twenty-five hours after the columns are filled, the drainage water from FLD and PLD columns and the bleeding water from the UD column are collected and weighed. The filled columns are then maintained under the backfill plant ambient conditions for a total curing time of 45 days.

These columns (or setups) allow the CPB to consolidate under geostatic stress loading and $\mathrm{K}_{0}$ condition (no PVC deformation). Because of the pasty nature of $\mathrm{CPB}$, it is assumed that any drained water is purely consolidation drainage (no free drainage). However, these setups can capture several coupled mechanisms such as self-desiccation [38], evaporation, etc.

\section{Plastic molds filling and curing condition}

To compare lab-scale (plastic molds) and intermediatescale (columns) samples performance, three undrained and three drained plastic molds $(7.6 \mathrm{~cm}$ diameter and $15.2 \mathrm{~cm}$ height) were poured with each mix recipe of CT1 backfill (columns 1,2 and 3) as control samples at LRD mine backfill plant. This makes a total of $6 \times 3=18$ molds of CT1 backfills (Fig. 7c). At the LVT mine backfill plant, however, six plastic molds $(10.16 \mathrm{~cm}$ diameter and $20.32 \mathrm{~cm}$ height) were filled with the CT2 backfill material.

All the filled molds CT1 backfill (LRD mine) and CT2 backfill (LVT mine) were caped and placed in a controlled humidity chamber at relative humidity $\mathrm{RH} \geq 90$ and $23 \pm 2{ }^{\circ} \mathrm{C}$. The curing times were 10,28 and 59 days for CT2 paste backfill, and 94, 98 and 102 days for CT1 paste backfill.

\section{Columns dismantling and test samples coring}

After each dedicated curing time, the PVC columns were carefully dismounted for recovering paste backfill columns. Each CPB column is then transversally cut out into a number of blocks between 10 and 12 using an electric disk cutter. The blocks are numbered starting from the top of each column. The coring of test specimens from each paste backfill block was carried out at the backfill plant using a concrete core cutter (Fig. 8).

Attempt has been made to obtain three test specimens per block, but generally two test specimens were obtained per block. A total of 60 and 68 core specimens were taken from the LVT mine CT2 backfill and LRD mine CT1 backfill, respectively. The obtained test specimens were wrapped in paraffin film (preventing them from drying), labeled and stored in a humidity chamber at the same curing conditions than for the plastic mold specimens (RH $>90 \%$ and $T=23 \pm 2{ }^{\circ} \mathrm{C}$ ).

\section{Unconfined compression tests}

The unconfined compression tests were performed on all test specimens for determining their uniaxial compressive strength (UCS). These tests were carried out using a servocontrolled mechanical press (MTS 10/GL) having a normal loading capacity of $50 \mathrm{kN}$, and tests were performed at a displacement rate of $1 \mathrm{~mm} / \mathrm{min}$. The aspect (height-to-diameter) ratio of all test specimens was around 2 . 


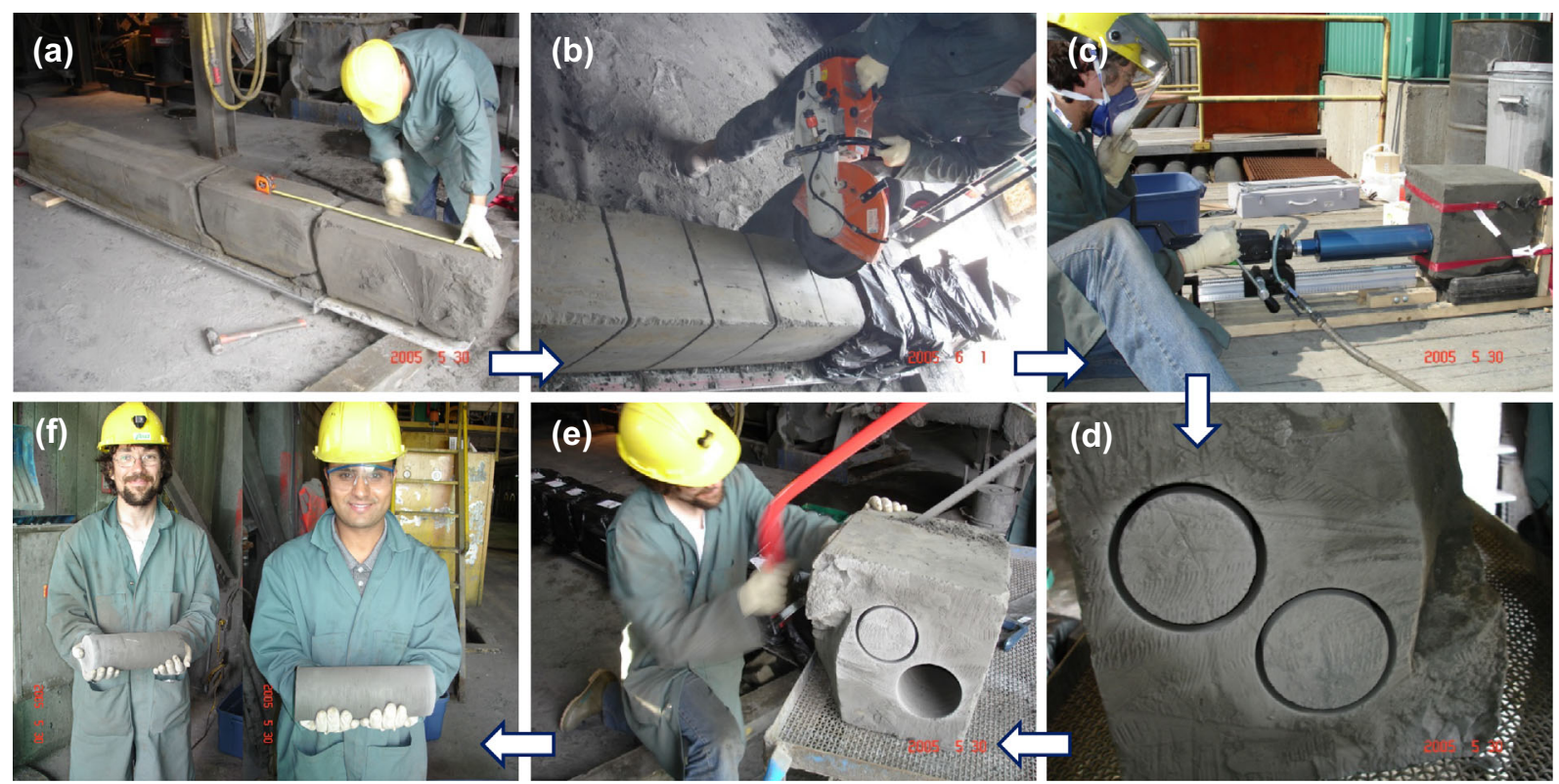

Fig. 8 Columns dismantling: a blocks sizing, $\mathbf{b}$ blocks cutting, $\mathbf{c}$ specimen coring, $\mathbf{d}$ end of coring, $\mathbf{e}$ specimen cutting, $\mathbf{f}$ obtained test specimens

\section{Results}

\section{Self-weight consolidation results}

The results of the CPB drainage water collection, self-weight settlement and vertical strain measurements are listed in Table 4. The percentage of drainage water is the ratio of the volume of drained water $\left(V_{\mathrm{w} \text {-drained }}\right)$ and the volume of initial water $\left(V_{\mathrm{w} 0}\right): 100 \times\left(V_{\mathrm{w}-\text { drained }} / V_{\mathrm{w} 0}\right)$. The vertical strain $\varepsilon_{\mathrm{v}}$ (which is equal to the volumetric strain in $K_{0}$ self-weight consolidation) is the ratio of the measured final settlement $\left(\Delta H_{\mathrm{f}}\right)$ to the initial height of backfill column $\left(H_{0}\right): \varepsilon_{\mathrm{v}}$ $(\%)=100 \times\left(\Delta H_{\mathrm{f}} / H_{0}\right)$. The self-weight consolidation settlement and drainage of all filled columns occurred mainly within the first 48-72 $\mathrm{h}$. That means that little or no drainage/ settlement occurs beyond $72 \mathrm{~h}$ after the column filling.

\section{LVT mine backfill (CT2) self-weight consolidation}

The percentage of drainage water was calculated to be $15.8 \%$ for the full lateral drainage (FLD) column and
$8.9 \%$ for the partial lateral drainage (PLD) column. This drainage corresponds to the final self-weight consolidation settlement $\left(\Delta H_{\mathrm{f}}\right) \quad$ of $\quad 16.4 \mathrm{~cm} \quad\left(\varepsilon_{\mathrm{v}}=5.5 \%\right), 8.5 \mathrm{~cm}$ $\left(\varepsilon_{\mathrm{v}}=2.8 \%\right)$ and $7.5 \mathrm{~cm}\left(\varepsilon_{\mathrm{v}}=2.5 \%\right)$ for FLD, PLD and UD columns, respectively. The observed CPB final settlement $\left(\Delta H_{\mathrm{f}}\right)$ measured from the top of the columns is also listed in Table 4. The observed LVT mine stope CPB settlement varies between 100 and $150 \mathrm{~cm}$ for a typical stope of $30 \mathrm{~m}$ high [11]. Figure $9 \mathrm{~d}-\mathrm{f}$ show the variation in the final vertical strain $\varepsilon_{\mathrm{v}}\left(=\Delta H_{\mathrm{f}} / H_{0}=\Delta V / V_{0}\right)$ calculated for the paste CT2 backfill as a function of elapsed time since the beginning of the filling.

\section{LRD mine backfill (CT1) self-weight consolidation}

Figure 9 shows the pore water pressure dissipation of the CT1 backfill for lower layers (layer 2) of the columns (Fig. 9a) and upper layers of columns (Fig. 9b) after the end of filling. Figure $9 a$ shows that the pore water pressure of the lower layers (layer 1 ) in column 1 dissipates $81 / 2$ days after the end of the column filling ( $\sim 100 \%$ consolidation).

Table 4 CPB self-weight consolidation data

\begin{tabular}{llllll}
\hline Mine site & Type of column & Drainage duration $(\mathrm{h})$ & $\%$ Drainage water $(\%)$ & Settlement $\Delta H_{\mathrm{f}}(\mathrm{cm})$ & Vertical strain $\boldsymbol{\varepsilon}_{\mathrm{v}}(\%)$ \\
\hline LVT (CT2) & FLD column & $\sim 72$ & 15.8 & 16.4 & 5.5 \\
& PLD column & $\sim 72$ & 8.9 & 8.5 & 2.8 \\
& UD column & - & - & 7.5 & 2.5 \\
\multirow{2}{*}{ LRD (CT1) } & Column 1 & $\sim 48$ & 17.5 & 12 & 4.1 \\
& Column 2 & $\sim 48$ & 25.8 & 14.4 & 5.0 \\
& Column 3 & $\sim 48$ & 19.7 & 12.4 & 4.3 \\
LVT mine & In situ stope & Unknown & Unknown & $100-150$ & $3.3-5.0$ \\
\hline
\end{tabular}


(a)

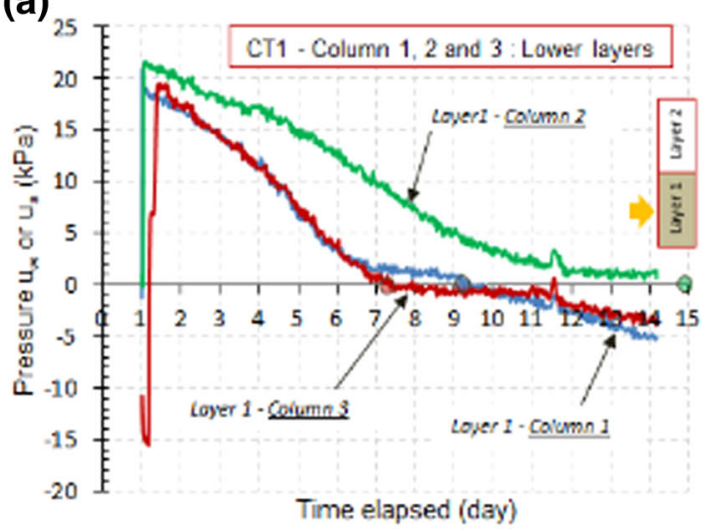

(b)

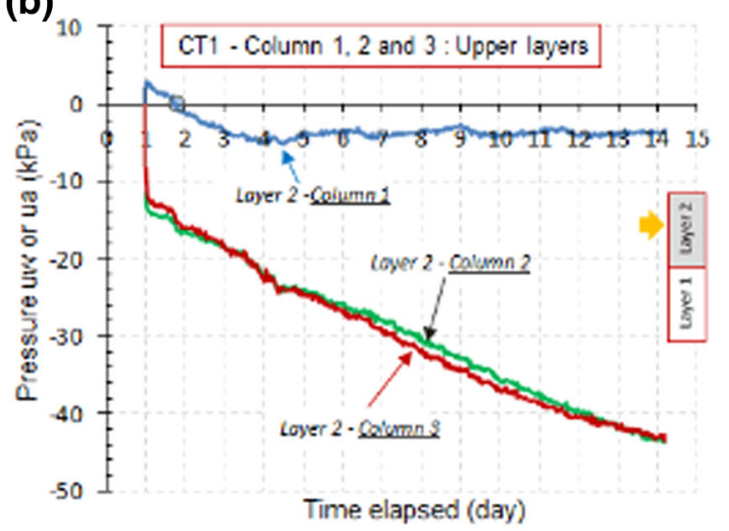

Fig. 9 Pore water pressure dissipation of backfills CT1: a lower layers or layer 1 and b upper layers or layer 2. From [37]

The end of consolidation in column 2 was observed around 14 days after the column filling and about 8 days in column 3 . It can be noticed that the consolidation behaviors of the lower layers in columns 1 and 3 are very similar (similar binder type) which differ from the lower layer of the column 2. Figure $9 \mathrm{~b}$ shows clearly that only the pore water pressure dissipation data of the column 1 are valid. Pore water pressure measured in the upper layer (layer 2) of column 1 is about $3 \mathrm{kPa}$, which is far below the hydrostatic pressure which would be around $10 \mathrm{kPa}$. Subsequently, the pore pressure dissipates fairly quickly within $18 \mathrm{~h}$ [37].

The percentage of drainage water was $17.5 \%$ for the column 1, $25.8 \%$ for the column 2 and $19.7 \%$ for the column 3 (see Table 4). The corresponding calculated vertical strain $\varepsilon_{\mathrm{v}}(\%)$ for these drainages was $4.1,5$ and $4.3 \%$ for the columns 1, 2 and 3, respectively. Figure 10ac show the variation in the final vertical strain $\varepsilon_{\mathrm{v}}$ calculated for the paste CT1 backfill as a function of elapsed time since the beginning of the filling.

From Fig. 10, it can be noticed that the calculated $\varepsilon_{\mathrm{V}}(\%)$ from the settlement $\left(\Delta H_{\mathrm{f}}\right)$ is much lower than the one from the drainage water. Indeed, calculated settlement-based strains were 5.0 and $5.5 \%$ for CT1-column 2 backfill and CT2-FLD column backfill, respectively. However, the calculated drainage water-based strains were 13.5 and $8.5 \%$ for backfill CT1-column 2 and backfill CT2-FLD column, respectively. The marked difference between the calculated drainage water-based and settlement-based vertical strains could be explained by the column filling sequencing. In fact, this difference may be due to the consolidation process occurring after the deposition of the layer 1 (bottom layer) during the first $12 \mathrm{~h}$ of the first day and before the layer 2 (top layer) is deposited. Also, this difference is much more pronounced in the case of the CT1 backfill at LRD mine (combination of vertical and lateral drainage) than for the CT2 backfill at LVT mine (lateral drainage only). Indeed, after its deposition, the layer 1 could drain its water and consolidates for a period of $12 \mathrm{~h}$ before the deposition of the layer 2, because the drainage valve was not closed. Such self-weight consolidation is accounted for by the collected drainage water but not by the settlement that was not measured manually, because the layer 1 was $1.5 \mathrm{~m}$ away from the top of the column. The measurement of settlement would have been possible using a laser measurement system which was not available. It should be mentioned that a big part of the unmeasured settlement due to the drainage of layer 1 is not taken into account in the measured final settlement $\Delta H_{\mathrm{f}}\left(=\Delta H_{\text {lay- }}\right.$ er1 $\left.+\Delta H_{\text {layer2 }}\right)$. On the other hand, the vertical strain $\varepsilon_{\mathrm{v}}$ calculated from the total drained water $V_{\mathrm{w} \text {-drained }}\left(=V_{\mathrm{w}-}\right.$ drained-layer1 $\left.+V_{\mathrm{w} \text {-drained-layer2 }}\right)$ is not very realistic, because the layer 1 was left for $12 \mathrm{~h}$ to consolidate under geostatic stress before the end of the column filling. However, the truth lies between the two, but much closer to the vertical strain calculated from the total vertical settlement. To avoid this complexity, the only solution should have been to fill the columns in one shot but keeping the drain valve closed prior to the start of the measurements. Nevertheless, only the values from settlement data are close to the in situ observations from LVT mine [11].

\section{Unconfined compressive strength results}

Figure 11 presents the variation in the unconfined compressive strength (UCS) of the columns backfill core specimens as a function of their location in each column at LRD mine (Fig. 11a) and LVT mine (Fig. 11b). The vertical straight lines shown in Fig. 11 correspond to the UCS average values obtained from the drained-curing (D) and undrained-curing (UD) plastic molds CPB specimens. It was assumed that the CPB's strength development in the column curing conditions (which mimic the in situ stope curing condition) is the coupling between a mechanical 
(a) Time elapsed (hour)

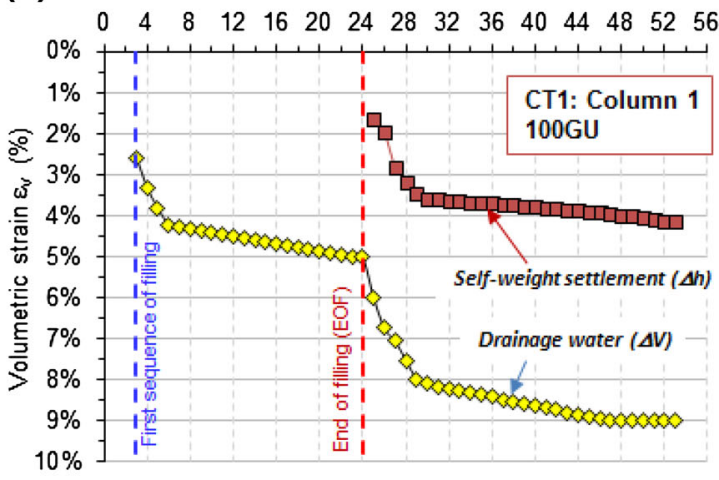

(b) Time elapsed (hour)

(b) $\quad \begin{array}{lllllllllllllll}0 & 4 & 8 & 12 & 16 & 20 & 24 & 28 & 32 & 36 & 40 & 44 & 48 & 52 & 56\end{array}$

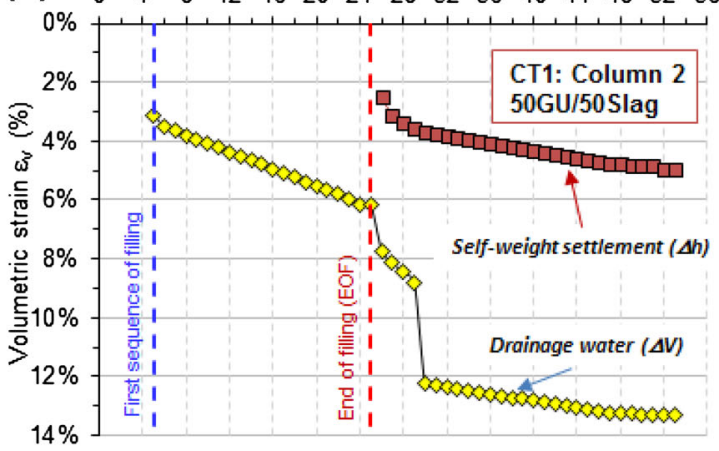

(c)

Time elapsed (hour)

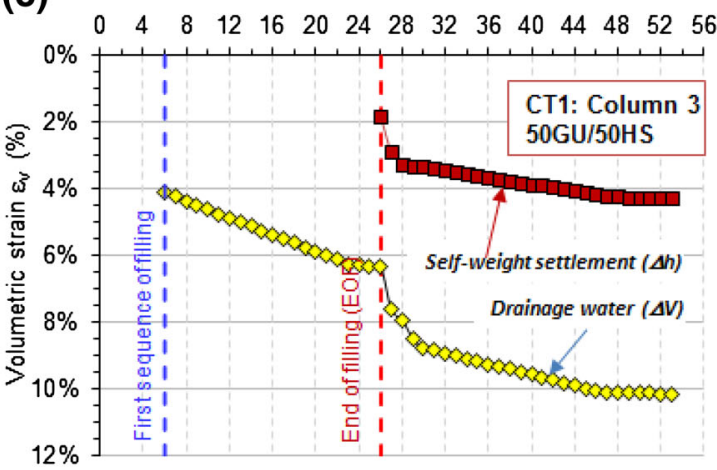

(d) Time elapsed (hour)

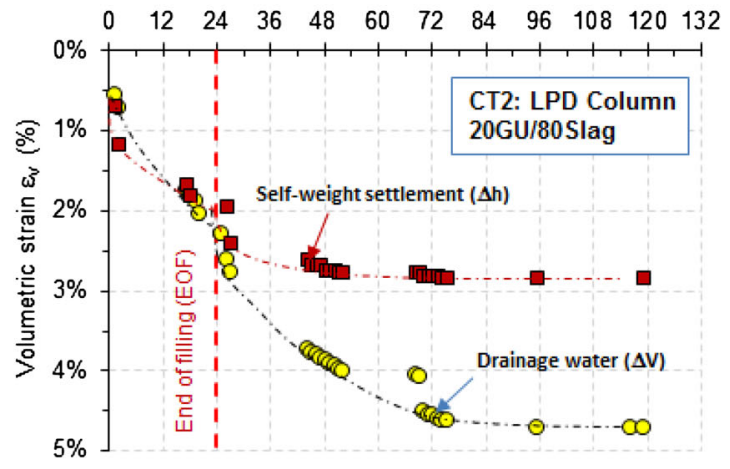

(e) Time elapsed (hour)

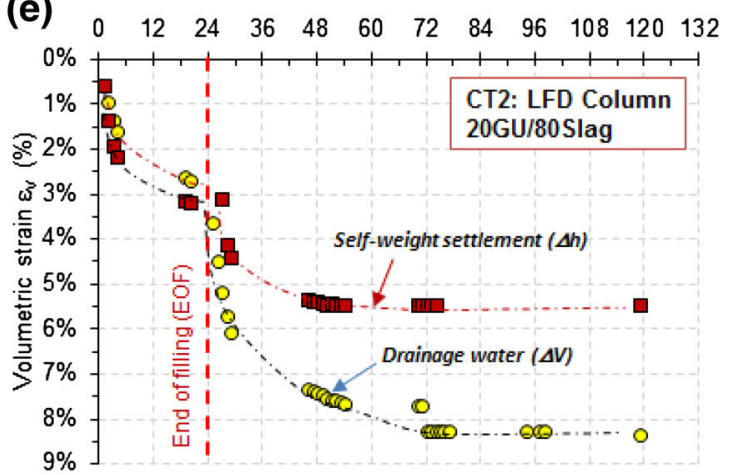

(f)

Time elapsed (hour)

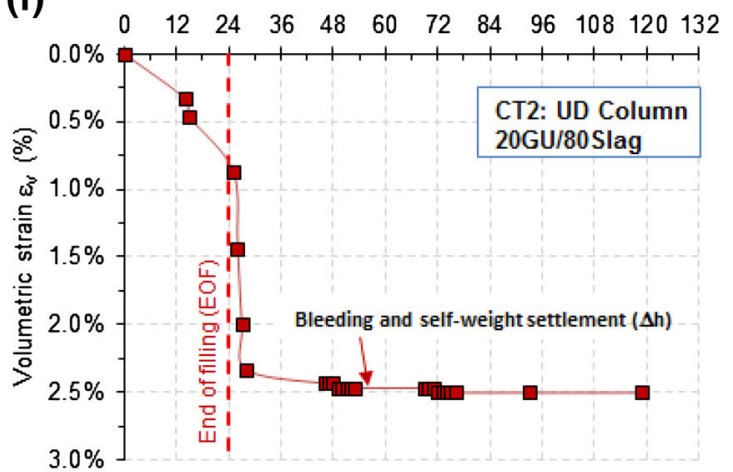

Fig. 10 Volumetric strain calculated from drainage water and settlement for backfills CT1 and CT2

action (=self-weight or gravity-driven consolidation including arching effect) and a chemical reaction (=binder hydration or backfill hardening and chemical shrinkage or self-desiccation).

Table 5 summarizes the UCS values obtained from both plastic mold backfill specimens (undrained-curing UD and drained-curing D) and the column CPB core specimens (CT2 backfill from LVT mine and CT1 backfill from LRD mine).

\section{LRD mine backfill (CT1) strength development}

Figure 11a shows that the average UCS value from undrained-curing mold CPBs is the lowest value of all, while the average UCS value from drained-curing mold specimens corresponds to an average UCS value from CT1 column 2 CPB specimens. Also, the UCS of drained-curing mold specimens is always higher than the one of undrained-curing mold specimens. This is suggesting that plastic molds underestimate the average values of UCS in the columns or even in real stopes. Also, the UCS from CT1 column 2 backfill specimens (after 98-day curing) is higher than the one from the CT1 column 3 backfill specimens (after 102-day curing) which, in turn, is higher than the one from the CT1 column 1 backfill specimens (after 94-day curing). It appears that the highest strengths were obtained on backfill specimens prepared with binder 

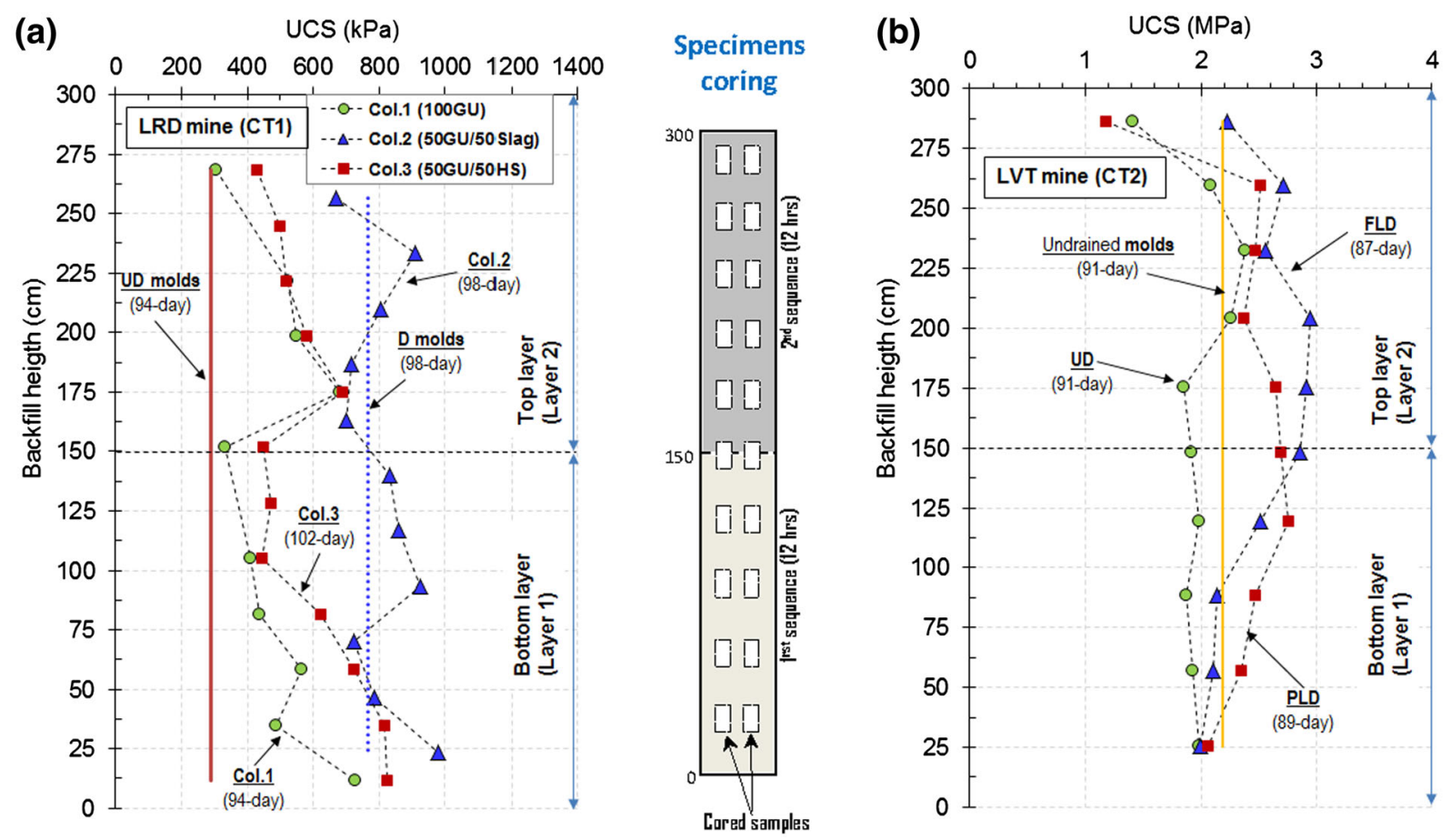

Fig. 11 UCS profiles of cemented paste backfill in six columns tested at LRD and LVT mines

Table 5 UCS values of the column and mold CPBs

\begin{tabular}{lllll}
\hline Columns & \multicolumn{2}{l}{ UCS (kPa) } & & \\
\cline { 2 - 5 } & Range & Average & UD molds & D molds \\
\hline LRD mine (CT1) & & & & \\
Column 1 (94-day) & $304-725$ & 501 & 291 & 515 \\
Column 2 (98-day) & $670-978$ & 809 & 586 & 767 \\
Column 3 (102-day) & $428-825$ & 588 & 362 & 650 \\
LVT mine (CT2) & & & & - \\
FLD (87-day) & $2000-2900$ & 2492 & 2140 & - \\
PLD (89-day) & $1200-2700$ & 2348 & 2160 & - \\
UD (91-day) & $1400-2400$ & 1963 & 2180 & \\
\hline
\end{tabular}

type $50 \% \mathrm{GU} / 50 \% \mathrm{Salg}$, regardless of the depth: $\mathrm{UCS}_{(\mathrm{GU}-\mathrm{Slag})}>\mathrm{UCS}_{(\mathrm{GU}-\mathrm{HS})}>\mathrm{UCS}_{(\mathrm{GU})}$.

The results show that the UCS of column-consolidated backfill samples slightly increases with depth. For GU binder (column 1) and GU-HS binder (column 3) backfill specimens, this increase follows the trend of overburden stress without arching effect $(\gamma h)$. From Fig. 11a, it can be observed that the average UCS values from undrainedcuring mold specimens, commonly used in quality control (QC) and design processes, correspond to the one of the top specimens of columns. This confirms the fact that UCS values obtained from plastic mold specimens can be considered as very safe. It can also be noticed that the average UCS value from column-consolidated paste backfill is closer to the one of drained-curing mold specimens. This suggests that the more realistic laboratory UCS values should at least be obtained from drained-curing mold samples only.

\section{LVT mine backfill (CT2) strength development}

Figure $11 \mathrm{~b}$ shows that the average UCS value from undrained-curing mold CPBs is almost always higher than the one of undrained column CPBs and is lower than the UCS value of the FLD and PLD paste backfills. This result suggests that backfilled stopes are probably partially or fully drained laterally. But it should be noted, however, that the molds do not take into account the sequencing of CPB filling in the columns and were not cured under the same conditions than the columns. For example, the top of the columns have been deliberately left open during the curing process under LVT mine backfill plant ambient air 
conditions, while the plastic molds were sealed and stored in a lab-controlled humidity chamber at RH $>90 \%$ and $T=23 \pm 2{ }^{\circ} \mathrm{C}$.

It can be observed from Fig. 11b that the UCS value is dictated by the column configuration and the sequence of filling. As a matter of fact, the UCS value of the FLD column paste backfill (CT2) is higher than the one of the PLD column paste backfill (CT2) in the layer 1 $(0-150 \mathrm{~cm})$, and is lower than the one of PLD backfill in the layer $2(150-300 \mathrm{~cm})$. Just after the layer 1 deposition $(0-150 \mathrm{~cm})$, the paste backfill drains a part of its water in the case of the FLD and PLD columns, but bleeds part of its water in the case of the UD column. After the layer 2 is deposited (150-300 cm), the PLD paste backfill could drain its water only through the backfill of layer 1 of $150 \mathrm{~cm}$ thick, whereas the FLD paste backfill can drain its water through the layer 1 as well as through the permeable geotextile joint. For the UD column, the initial bleeding water at the top of CPB layer 1 is believed to be imprisoned by the layer 2, and once the column is filled, there is again a water separation (bleed) on the top surface of the backfill; a part will evaporate and other will re-integrate the backfill mass.

\section{Concluding remarks}

This paper presents the results of a prospective experimental study on self-weight consolidation behavior and strength development of cemented paste backfill poured into settling columns of $3-\mathrm{m}$ high. The tests were performed at two different mines paste backfill plants, namely LRD (CT1 backfill) and LVT (CT2 backfill) mines. Four different backfill mix recipes formulation $(100 \% \mathrm{GU}$, $50 \% \mathrm{GU} / 50 \% \mathrm{Slag}, 50 \% \mathrm{GU} / 50 \% \mathrm{HS}$ and $20 \% \mathrm{GU} /$ $80 \%$ Slag) and four column drainage scenarios (UD, PLD, FLD and FLD + vertical drainage) were tested. Conventional plastic molds were also used to get lab-scale control specimens.

The results showed that the total percentage of drainage water and the maximum observed self-weight consolidation settlement occur mainly within the first $48-72 \mathrm{~h}$ since the columns are filled. The maximum drainage percentage varied between $9 \%$ (CT2-PLD column) and $26 \%$ (CT1column 2) of the initial total water of CPB.

The maximum measured CPB self-weight consolidation settlement $\Delta H_{\mathrm{f}}$ was of $16.4 \mathrm{~cm}$ (CT2-FLD column) and the minimum was of $7.5 \mathrm{~cm}$ (CT2-UD column). The corresponding vertical strains $\varepsilon_{\mathrm{v}}(\%)$ varied between $2.5 \%$ (CT2-UD column) and $5.5 \%$ (CT2-FLD column). The field-observed volumetric strain of $\mathrm{CPB}$ at LVT mine varies between 3.3 and $5.0 \%$, which is suggesting that in situ backfilled stopes behave in a similar way to the full lateral drainage (FLD) or the partial lateral drainage (PLD) conditions.

The unconfined compression test results showed that the compressive strength (UCS) of the undrained mold specimens, commonly used in quality control and design processes, correspond to the one of specimens from the top of columns. The average UCS value of column-consolidated paste backfill is closer to the one from drained mold specimens (suggesting that the more realistic laboratory UCS values should be obtained from drained mold specimens only).

The maximum UCS value was obtained at the bottom of columns, probably due to highest self-weight consolidation (compactness). The LVT backfill strengths are clearly much higher than the strengths of the LRD backfill.

Under equal conditions, it appears that the highest strengths were obtained on backfill specimens prepared with $50 \%$ GU/50\% Slag formulation, regardless of the depth: $\mathrm{UCS}_{(\mathrm{GU}-\mathrm{Slag})}>\mathrm{UCS}_{(\mathrm{GU}-\mathrm{HS})}>\mathrm{UCS}_{(\mathrm{GU})}$.

Further in situ investigations using adequately instrumented columns are needed to better understand the effect of self-weight consolidation of paste backfill on its shortand long-term mechanical, physical and geochemical behaviors.

Acknowledgments This research was financially supported through an NSERC Discovery Grant and the Fondation de l'Université du Québec en Abitibi-Témiscamingue (FUQAT) Grant. The authors acknowledge and are grateful for this financial support. The authors would also like to sincerely thank their industrial partner, Agnico Eagle Mines Ltd, (LRD Mine), for providing technical and logistical supports throughout the project. The authors would like to acknowledge individuals such as Nil Gaudet, Hugues Bordeleau, Franck Gagnon, Bernard Dallaire, Jean Cayouette and Mathieu Belisle for the invaluable technical assistance throughout this project.

\section{References}

1. Potvin Y, Thomas EH, Fourie AB (2005) Handbook on mine fill. ACG Publication, Perth

2. Belem T, Benzaazoua M (2008) Underground paste backfill technology: applications and design methods. Geotech Geol Eng 26(2):147-175

3. Yilmaz E, Belem T, Benzaazoua M (2014) Effects of curing and stress conditions on hydromechanical, geotechnical and geochemical properties of cemented paste backfill. Eng Geol 168(1):23-37

4. Belem T, Benzaazoua M, Bussière B, Dagenais AM (2002) Effects of settlement and drainage on strength development within mine paste backfill. In: Proceedings of tailings and mine waste' 02 , pp 139-48

5. le Roux KA, Bawden WF, Grabinsky MWF (2005) Field properties of cemented paste backfill at the Golden Giant mine. Miner Technol IMM Trans Sect A 114(2):65-80

6. Thompson BD, Grabinsky MW, Bawden WF (2012) In-situ measurements of cemented paste backfill at the Cayeli Mine. Can Geotech J 49(7):755-772 
7. Thompson BD, Grabinsky MW, Bawden WF (2012) In situ monitoring of cemented paste backfill pressure to increase backfilling efficiency. CIM J 2(4):199-209

8. Yilmaz E, Belem T, Benzaazoua M, Bussière B (2010) Assessment of the modified CUAPS apparatus to estimate in situ properties of cemented paste backfill. Geotech Test J 33(5):351-362

9. Yilmaz E, Belem T, Benzaazoua M (2012) One-dimensional consolidation parameters of cemented paste backfills. Miner Resour Manag 28(4):29-45

10. le Roux KA, Bawden WF, Grabinsky MWF (2002) Assessing the interaction between hydration rate and fill rate for a cemented paste backfill. In: Proceedings on 55th Canadian geotechnical and 3rd joint IAH-CNC groundwater specialty conference, pp 427-432

11. Cayouette J (2003) Optimization of the paste backfill plant at Louvicourt mine. CIM Bull 96(1075):51-57

12. Revell MB (2004) Paste-how strong is it? In: Proceedings of 8th international symposium on mining with backfill, pp 286-294

13. Belem T, Harvey A, Simon R, Aubertin M (2004) Measurement and prediction of internal stresses in an underground opening during its filling with cemented fill. In: Proceedings of 5th international symposium on ground support in mining and underground construction, pp 619-630

14. Grabinsky MW, Bawden FW (2007) In situ measurements for geomechanical design of cemented paste backfill systems. CIM Bull 100(1103):18-28

15. Benzaazoua M, Fall M, Belem T (2004) A contribution to understanding the hardening process of cemented pastefill. Miner Eng 17(2):141-152

16. Belem T, Benzaazoua M, Bussière B (2000) Mechanical behaviour of cemented paste backfill. In: Proceedings of 53th Canadian geotechnical conference, vol 1, pp 373-380

17. Belem T, Bussière B, Benzaazoua M (2001) The effect of microstructural evolution on the physical properties of paste backfill. In: Proceedings on tailings and mine waste'01, pp 365-374

18. Belem T, El-Aatar O, Bussière B, Benzaazoua M, Fall M, Yilmaz E (2006) Characterization of self-weight consolidated paste backfill. In: Proceedings of 9th international seminar on paste and thickened tailings-paste'06, pp 333-345

19. Fourie A, Helinski M, Fahey M (2006) Filling the gap-a geomechanics perspective. Newsletter 26:18-24

20. Fourie AB, Fahey H, Helinski M (2007) Using effective stress theory to characterize the behaviour of backfill. CIM Bull 100(1103):1-9 (Paper 27)

21. Helinski, M, Fourie, AB, Fahey, M (2006) Mechanics of early age cemented paste backfill. The 9th international seminar on paste and thickened tailings, Limerick, Ireland, April 3-7, pp 313-322

22. Helinski M, Fahey F, Fourie AB (2007) Numerical modelling of cemented paste backfill deposition. J Geotech Geoenviron Eng ASCE 13(10):1308-1319

23. Helinski M, Fourie AB, Fahey M (2009) Preliminary results from an investigation into the effect of application of effective stress to cemented paste backfill during curing. Newsletter, Australian Centre for Geomechanics (ACG), 31(12), 10-13
24. Yilmaz E, El Aatar O, Belem T, Benzaazoua M, Bussiere B (2006) Effect of consolidation on the performance of cemented paste backfill. The 21st conference on underground mine support, Val d'Or, Quebec, Canada, April 11-12, pp 1-14

25. Yilmaz E, Belem T, Benzaazoua M, Bussiere B (2008) Experimental characterization of the influence of curing under stress on the hydromechanical and geotechnical properties of cemented paste backfill. The 12th international conference on tailings and mine waste, October 18-23, Vail, Fort Collins, Colorado, USA. Taylor \& Francis Group, London, pp 139-152

26. Yilmaz E, Benzaazoua M, Belem T, Bussière B (2009) Effect of curing under pressure on compressive strength development of cemented paste backfill. Miner Eng 22(9-10):772-785

27. Fahey M, Helinski M, Fourie A (2009) Some aspects of the mechanics of arching in backfilled stopes. Can Geotech J 46:1322-1336

28. Fahey M, Helinski M, Fourie A (2010) Consolidation in accreting sediments: Gibson's solution applied to backfilling of mine stopes. Geotechnique 60(11):877-882

29. Belem T, Benzaazoua M, El Aatar O, Yilmaz E (2013) Effect of drainage and the pore water pressure dissipation on the backfilling sequencing. In: Proceedings of the 23rd world mining congress, Canada, August 11-15, pp 1-10

30. Yumlu M, Guresci M (2007) Paste backfill bulkhead monitoring: a case study from Inmet's Cayeli Mine, Turkey. CIM Bull 100(1103): $1-10$

31. Been K, Sills GC (1981) Self-weight consolidation of soft soils: an experimental and theoretical study. Géotechnique 31(4):519-535

32. Wickland BE, Wilson GW (2005) Self-weight consolidation of mixtures of mine waste rock and tailings. Can Geotech $\mathrm{J}$ 42:327-339

33. Yilmaz E, Belem T, Bussière B, Mbonimpa M, Benzaazoua M (2015) Curing time effect on consolidation behaviour of cemented paste backfill containing different cement types and contents. Constr Build Mater 75:99-111

34. Yilmaz E, Belem T, Benzaazoua M (2013) Study of physicochemical and mechanical characteristics of consolidated and unconsolidated cemented paste backfills. Miner Resour Manag 29(1):81-100

35. Yilmaz E, Belem T, Benzaazoua M (2012) One-dimensional consolidation parameters of cemented paste backfills. Miner Resour Manag 28(4):29-46

36. Yilmaz E, Belem T, Benzaazoua M, Bussière B (2010) Assessment of the modified CUAPS apparatus to estimate in situ properties of cemented paste backfill. Geotech Test J 33(5):351-362

37. El Aatar O (2011) Étude de la consolidation gravitaire en colonnes des remblais miniers cimentés en pâte". Mémoire de maîtrise ès sciences appliquées (génie minéral). École polytechnique Montréal, Canada, p 191

38. Helinski M, Fourie AB, Fahey M, Ismail M (2007) The selfdesiccation process in cemented mine backfill. Can Geotech $\mathrm{J}$ 44(10):1148-1156 